When rationality fails: Making sense of the 'slippery slope' to corporate fraud

\author{
Paolo Campana \\ Institute of Criminology, \\ University of Cambridge, \\ United Kingdom
}

Corresponding address

Institute of Criminology, University of Cambridge

Sidgwick Avenue, Cambridge CB3 9DA, United Kingdom

Email:pc524@cam.ac.uk

Phone: +44 1223767375

Version submitted for publication in Theoretical Criminology

Accepted on 22.09.2015 


\title{
When rationality fails: Making sense of the 'slippery slope' to corporate fraud
}

\begin{abstract}
Management fraud is often explained through wealth-maximisation paradigms. This paper invokes a different approach, namely a behavioural one, and argues that fraud may happen as a consequence of failures in the decision-making process. Relying on extensive evidence in the case of Parmalat, it maintains that this fraud was not brought about by the desire of the CEO, chairman and founder to maximise his economic goals, but was rather a consequence of his failure to produce an objective description of reality. This was induced by a number of behavioural mechanisms such as self-deception, managerial hubris, emotions and the 'endowment effect'. This paper also contributes to a broader debate on the rationality of economic actors and its limits, and sheds light on the seeds of potential crises contained within genuine Schumpeterian entrepreneurs.
\end{abstract}

Keywords: management fraud, rationality failures, self-deception, overconfidence, emotions, behavioural law and economics.

\section{Acknowledgements}

I am most grateful to Federico Varese for his extremely helpful comments on earlier versions of this paper, and to the Editors and the Referees for their very insightful comments. This work has also greatly benefitted from comments by Rupert Younger, Rowena Olegario, Mark Hughes-Morgan, Julian Roberts and Peter Reuter. Gabriele Capolino, Stefania Chiaruttini, Bianca Frondoni and Vittorio Malagutti were extremely generous with their time and offered invaluable assistance in the data collection. Maurizio Catino provided some preliminary insights on the topic. I am also grateful to audiences at the European Society of Criminology Conference (Bilbao, 12-15 September 2012), the $14^{\text {th }}$ Cross-border Crime Colloquium (Cambridge, 12-14 May 2013) and the $25^{\text {th }}$ Annual Conference of the Society for the Advancement of Socio-Economics (Milan, June 27-29 2013). This work has received generous financial support from the Centre for Corporate Reputation, Said Business School Oxford, which I gratefully acknowledge. This research received no specific grant from any funding agency in the public, commercial, or not-for-profit sectors. The author declares that he has no relevant or material financial interests that relate to the research described in this page. 


\section{When rationality fails: Making sense of the 'slippery slope' to corporate fraud}

\section{Introduction}

Following the discovery of a $€ 14 \mathrm{bn}$ fraud, the dairy and food multinational company Parmalat collapsed in December 2003 in what amounts to one of the biggest bankruptcies ever to have happened in Europe. For 42 years, the company had been led by its founder, Calisto Tanzi, who also served as CEO and chairperson at the same time. After the collapse, he was handed a combined jail sentence in excess of 20 years.

The case of Parmalat is not unique in the corporate landscape. Top management fraud is "a worldwide problem that cut across ideological and cultural divides" (Zahra et al. 2005: 804), as shown by the cases of Enron and WorldCom in the US, Olympus in Japan, Lernout \& Hauspie in Belgium, the Bank of Credit and Commerce International in the UK, just to name a few. Management fraud consists in "the deliberate actions taken by management at any level to deceive, con, swindle, or cheat investors or other key stakeholders' (Zahra et al. 2005: 804); they may take a variety of forms, including intentional misrepresentation of financial statements and failures to properly disclose company's activities. In some instances, fraud may lead to the collapse of a company. In addition, they may also indirectly impact other companies operating in the same sector. While a good deal of work has investigated the technicalities of fraudulent financial reporting (see, e.g., COSO 1999; COSO 2010), there is still a need to gain a deeper understanding of the motivations behind managements fraud and to debunk some often-cited narratives around them. 
Calisto Tanzi is an interesting case in point. He was a genuine and innovative industrialist who set up his own company with a clear industrial goal. He was then able to turn it into a multinational corporation, gaining personal wealth and recognition. Over the years, he built a reputation for being a dedicated and principled entrepreneur, rather retiring and extremely religious. ${ }^{1}$ In one instance he made available for free his private jet to a young person in need of urgent medical treatment. ${ }^{2}$ As I shall discuss in the remainder of the paper, the profile of Calisto Tanzi closely resembles the ideal-typical Schumpeterian entrepreneur, who is driven by "the dream and the will to found a private kingdom usually, though not necessarily, also a dynasty" as well as a "will to conquer" and "a joy to create" (Schumpeter 1934: 93). According to Schumpeter (1934: 74), it is precisely this specific type of economic actor that constitutes the driving force in fostering economic development. Yet, the same Schumpeterian entrepreneur embodied by Calisto Tanzi intentionally embarked on an unlawful path that would eventually destroy nearly everything he had managed to create. It is rather puzzling why entrepreneurs who have strived to promote innovation and generate wealth throughout their career may not be deterred from entering an unlawful path by the (severe) expected consequences of their actions. These consequences may include the loss of the company they created as well as the loss of their personal wealth and reputation - not to mention prison terms.

\section{Structure of this article}

This paper is an attempt to better grasp the mechanisms underlying the "slippery slope" to major fraud (for a typology of fraud, see Levi 2008: xix). It relies on a vast range of empirical evidence, including court files, reports by the expert advisor to the prosecutor's office, sworn testimonies 
and transcripts of police interrogations, author's interviews with key informants, and official documents. The article proceeds as follows: Section one first discusses the often cited 'greed explanation' of corporate fraud and qualifies it as a wealth-maximisation desire held by rational economic actors, and then introduces a possible alternative explanation based on a behavioural approach to individual decision-making. Section two briefly retraces the story of Parmalat and offers some insights into the fraud. The evidence supporting a wealth-maximisation explanation of Tanzi's behaviour is assessed in Section three. Section four discusses an alternative behavioural explanation for Tanzi's decision-making process. Section five briefly looks at mechanisms underpinning the escalation stage of the fraud. Finally, Section six offers some conclusions.

\section{Is the love of money "the root of all evil"?}

Greed is often cited as a key factor underpinning corporate scandals and, more generally, corporate misbehavior (Cruver 2002; Partnoy 2003; Bryce 2004; Kothari 2010). In a testimony before a US Senate Committee in 2002, the then President of the Federal Reserve, Alan Greenspan, famously noted that "an infectious greed seemed to grip much of our business

community". ${ }^{3}$ Kothari (2010: xv-Xvi) linked the "inappropriate leadership actions" that happened in the context of recent financial scandals, including Enron, WorldCom and Tyco, to "unbridled personal greed at the highest level in the corporate world”. KPMG (2010: 10) surveyed a sample of 214 instances of fraud in Australia and New Zealand and found that in almost $93 \%$ of the cases greed and lifestyle were cited as the motivating factor. Braithwaite (1992) has suggested that, as we move up the social class ladder, need is replaced by greed as the motivating factor 
behind crime. Hamilton and Micklethwait (2006: 4) listed a number of companies whose 'greedy' CEOs have brought to bankruptcy, including Parmalat. This view is shared by the judges at the Bologna Court, according to whom Tanzi's greed was "an incurable disease which makes the accumulation of wealth an ominous activity and an end in itself, and that does not deserve any supplementary explanation". However, as catchy as they may be, these explanations are still largely unsatisfactory and require some further scrutiny.

Arguably, the explanations discussed above are premised on a notion of greed that emphasises its materialistic element. This is in line with the definition included in the Cambridge Dictionary of English (“a very strong wish to continuously get more of something, especially food or money”). According to Wheeler (1992: 112), greed can be interpreted as a strong preference for wealthmaximisation. The same emphasis underpins Arjoon's explanation of the "acts of criminal commission" perpetrated by well-respected corporate leaders and top executives, and denoted by "an insatiable drive to acquire wealth as the only thing that matters" (Arjoon 2008: 80). Individuals involved in these acts are defined as 'egoists' and described as 'individualistic, opportunistic, self-serving" as well as possessing a "materialistic outlook, driven by greed" (Arjoon 2008: 81). Indeed, greed was also linked to materialistic incentives in the words of an 'elite' white-collar fraudster interviewed by Schuchter and Levi (2015: 8): "It is driven by greed. The incentive was tangible in my case, so materialistic".

Formally, one can situate this perspective within a rational choice approach. Such an approach is an obvious candidate to explain the behaviour of economic actors, and particularly business people with a track record of success and innovation. Successful entrepreneurs may be taken to epitomise the quintessential rational calculator driven by his desire to maximise utility, and, in particular, wealth. Rational choice theory then predicts that these individuals would be willing to 
embark on an unlawful course of action only if they believe that the economic benefit of their conduct will exceed the anticipated costs (Kagan and Scholz 1980; more generally Becker 1974). Several authors have suggested applying a formal model of deterrence based on a cost-benefit calculation to explain corporate crime. Kadish (1977: 305) moves from the assumption that crimes perpetrated by corporate offenders are "calculated and deliberative" and mainly directed towards economic gains. Chambliss (1967: 713) maintains that the offences committed by whitecollar criminals are instrumental and not expressive. According to Braithwaite and Geis (1982: 302), "corporate crimes are almost never crimes of passion; they are not spontaneous or emotional, but calculated risks taken by rational actors". Braithwaite and Makkai (1991) present a deterrence model for corporate crime based on a cost-benefit utility function. Paternoster and Simpson (1993: 40-47, also 1996) expand on the previous literature by postulating a utility function of corporate offenders that includes instrumental and non-instrumental variables (e.g. moral beliefs and perceived legitimacy of rules and rule enforcers). Paternoster and Simpson (1993: 40-41) also maintain that, ultimately, "the decision by would-be offenders to commit a crime is a rational decision that is affected by the perceived costs and benefits of the actions".

However, decisions and choices may be subject to biases and systematic errors. The behavioural approach to decision-making moves from the observation that the impact of biases and errors in judgment may be larger than what a classical rational choice approach postulates, and offers an alternative model to explain individual actions that challenges the optimisation principle at the basis of rational choice models (see, e.g., Sunstein 2000). 
Individuals are indeed subject to the limits of a "bounded rationality" (Simon 1955; March and Simon 1958); crucially, they are also subject to a number of potential sources of errors when making their judgments (Kahneman and Tversky 1972; Tversky and Kahneman 1974; see also Kahneman 2011). It has been shown that these systematic errors may be the consequence of the use of heuristics; individuals have also been shown to overweight improbable outcomes ('possibility effect') and to be influenced by optimism and overconfidence (Kahneman and Tversky 1972; Tversky and Kahneman 1974; also, among others, Sunstein 2000; Baron 2008; Thaler and Sunstein 2009; Kahneman 2011). A major amendment to classical rational choice models is that the preference order possessed by an individual is not assumed to be stable, but is instead dependent on the current reference point (Kahneman et al 1991: 205). In addition, individuals who own possessions display a tendency to resist selling these possessions more than "a conventional rational model would predict" (Rachlinski and Jourden 1998: 1553). This is also known as the 'endowment effect', that is the tendency for individuals to "demand much more to give up an object than they would be willing to pay to acquire it" (Kahneman et al 1991: 194).

In risk situations, heuristic devices can lead to negative consequences (Sunstein 2000: 3). Langevoort (2000: 147, italics in the original) suggests the possibility that managers may be subject to 'behavioural risks' stemming from biases that cause them "to misperceive events and risks; allowing them in good faith to perpetuate an unrealistic belief system in the face of external stress". Managers may show a tendency to "ignore evidence of change in one's environment", and to "construe information and events in such a way as to confirm prior attitudes, beliefs and impressions" (Langevoort 2000: 148). Furthermore, individuals may be subject to unrealistic optimism, thus taking risks "because of a factually false belief in their own relative immunity from harm, even if they are fully aware of the statistical facts" (Sunstein 2000: 
3). Indeed, managers have been found to possess a systematic tendency to overrate their own ability: "this egocentric bias readily takes the form of excessive optimism and overconfidence, coupled with an inflated sense of ability to control events and risks" (Langevoort 2000: 149). There is evidence of unrealistic optimism among both MBA students and people starting new businesses (Cooper, Woo, and Dunkelberg 1988; Hayward, Shepherd and Griffin 2006; Thaler and Sunstein 2009: 34). In addition, managerial hubris has been shown to play a role in corporate takeovers, often leading to less than optimal outcomes (Roll 1986; Hayward and Hambrick 1997; Malmendier and Tate 2008). Finally, the role that emotions play in decision-making may be greater than what it is often recognised (Elster 1999: 328-331). For instance, 'affect heuristics' may lead individuals to systematically underestimate the risks posed by objects that they happen to like more (Kahneman 2011: 140).

According to Langevoort (2000: 152), corporate malfeasance can be the product of the "ability of normal people in stressful environment to distort and rationalize" more than a "base moral corruption" (Langevoort 2000: 152). In his analysis of the Enron bankruptcy case, Salter (2008: 49) maintains that the "the root of the company's troubles and eventual collapse was not premeditated crime, but rather hubris and a certain recklessness or fearlessness and the lack of operating experience". Overconfidence, narcissism and hubris seem to have played a major role among the top executives. Moreover, Kenneth Lay, Enron's CEO for almost 17 years until the collapse, was deemed to possess "a well-developed capacity for self-delusion about harsh truths he did not want to face" (Salter 2008: 103). Lay and other key executives "systematically refused to confront investment mistakes and their own incompetence"; they had a tendency to behave defensively, that is, to cling to their "beliefs in the face of overwhelmingly contrary evidence" (Salter 2008: 103). Defensive behaviour, Salter maintains, is not rational. 
Levi (2008) has explored the motivations of the individuals who set up companies with the specific intent of defrauding people in 'pre-planned frauds' (p. xvii). Based on a thorough assessment of a large wealth of empirical evidence, he has convincingly concluded that these individuals were mostly driven by pure economic motivations. A wealth-maximisation paradigm is arguably the best candidate to explain this set of bankruptcy fraud. There is, however, a different type of fraud, labelled 'slippery-slope frauds' and defined by Levi (2008: xix) as cases "in which deceptions spiralled, often in the context of trying - however absurdly and overoptimistically - to rescue an essentially insolvent business or set of businesses". Arjoon (2008: 78) defines a slippery slope as "a gradual decline [in the ethical behaviour] in which no one event makes one aware that he or she is acting unethically". What happens when we look at the 'slippery-slope' to corporate fraud? Would a wealth-maximisation paradigm still be the best candidate to explain these instances? This paper is an attempt to further explore slippery-slope fraud, and to assess the extent to which the Parmalat fraud was the result of a rational decision taken by a greedy yet rational calculator or, rather, a consequence of some biases affecting the decision-making process of the man at its head.

\section{Parmalat: The evolution from a local business to a multinational company}

The story of Parmalat begins in Collecchio, a small Italian town on the outskirts of Parma, where in 1961 a 22-year-old entrepreneur, Calisto Tanzi, set up his own business. Tanzi comes from a family of entrepreneurs: his grandfather was the founder of a small company specialising in the production of tomato sauce and salami and their distribution in the nearby provinces. ${ }^{5}$ Tanzi's 
first steps were rather encouraging, and in two decades he was to make a significant contribution to changing the Italian dairy sector. He soon proved to be a genuine "entrepreneur" in Schumpeterian terms: that is to say, an individual who actually carries out a new combination of means of production and credit, and thus generates the "fundamental phenomenon of economic development" (Schumpeter 1934: 74).

In the 1960s Tanzi introduced some truly revolutionary ideas into the Italian market. He first replaced the widely used glass bottles with Tetra Pak bricks; he then launched the innovative pasteurised milk enriched with vitamin C and two years later he was the first to use UHT technology for processing milk (Buchanan and Yang 2005: 48). In the early seventies he took full advantage of the liberalisation process in the Italian retail market for milk and increased Parmalat's turnover at a staggering pace (Malagutti 2004: 68-69; see also Buchanam and Yang 2005: 48-9). At the same time, the company first diversified its production within dairy farming and then, over the following decade, it started to sell a whole new range of products, including bakery products, beverages, tomato sauces and vegetables (Chiaruttini 2004a: 55). In 1974 the group landed in Brazil (Franzini 2004: 74). By the end of 1991, Parmalat was running 30 plants in four countries, employing 4,839 people (Chiaruttini 2004a: 55).

Between 1990 and 2003, Parmalat carried out a massive campaign of acquisitions in both the domestic and international markets (more than 100 companies worldwide), which made it the biggest Italian food company, the eighth-largest industrial company in the country and one of the world's largest independent milk and dairy producers (Buchanan and Yang 2005: 35). By 1998, the group had gained a truly transnational reach with investments in several countries, including Canada, Australia, Brazil and the other six Latin American markets, South Africa, the US, 
Russia and even China and India (Chiaruttini 2004a: 56-58 and 62-63). At the end of December 2002, Parmalat ran 139 plants and employed 36,356 people.

In the seventies and eighties, Parmalat was indeed growing at a rapid pace but was also showing some vulnerability. Two factors posed the greatest risk to the long-term stability of the company. Firstly, the corporate structure quickly became inadequate to manage such a fast-growing enterprise, coordinating its strategy and effectively overseeing all the international activities. Secondly, according to the official reports issued by Parmalat itself, the company was growing in size but generating small profits (Malagutti 2004: 74). In 1989 Parmalat was short on financial resources and in need of recapitalisation; Tanzi and his family were short of money, too, so they decided to turn to the capital market, listing the company on the Milan Stock Exchange (1990). However, even after having gone public, Parmalat's financial situation remained fragile. The company was suffering from a consistently low cash flow, and had to turn to the national and international market for capital more and more over the years. Between 1994 and 2003, Parmalat collected a total of $€ 11.5$ billion through 50 bonds and 38 private placements with the assistance of a number of leading international banks from both Europe and the US (Chiaruttini 2004a: 61, Table 14; also 59-61). Indeed, investors showed a high degree of trust in the company: as it turned out, this trust was completely misplaced. According to Fausto Tonna, a former chief financial officer, the company started to alter its balance sheet from 1994 following a crisis faced by the South American subsidiaries and some blatant strategic errors (e.g. overly optimistic sales targets; Parma Court of First Instance 2010: 1251). In perpetrating the fraud, Parmalat resorted to a whole array of creative accounting tactics, irregularities and overt falsifications. These include the creation of off-shore companies to be used as "accounting dumps" to which bad loans were 
transferred; the forgery of bank statements and accounting books to show billions of euros of non-existent liquidity used to offset the high level of debt; the creation of a fictitious hedge fund to generate fake liquidity and bogus currency swaps; fictitious sales of powdered milk on the Cuban market; and fake repurchases of the company's bonds. ${ }^{6}$

\section{INSERT FIGURE 1 HERE}

Figure 1 shows the net total of the company's cash inflow from the financial markets (labelled: Financing Activities) minus the cash outflow directed towards investments (labelled: Investing Activities). ${ }^{7}$ Until 1993, investing activities exceeded financing activities. In 1994-95 the two measures balanced out. From 1996 onwards the net total of financing against investment increases steadily. When the outflow of cash for investments becomes consistently smaller than the inflow from financing activities, there is a strong suspicion that something is not working in the right direction. At the same time, professed liquidity increased steadily (the year 1996 is, again, a turning point): as would be clear in December 2003, a substantial part of that liquidity simply never existed. If we take the level of liquidity as a proxy for the size of the fraud, it becomes apparent how quickly it escalated from 1996 onwards. It is therefore plausible that the fraud which led the company to bankruptcy started around 1994, as stated by the former CFO, and it escalated from 1996 onwards at a considerably fast pace. After going undetected for at least a decade, the fraud reached the staggering level of some $€ 14 \mathrm{bn}$ in December 2003. 


\section{Assessing the wealth-maximisation explanation}

Why had Calisto Tanzi decided to enter the slippery terrain that led to the fraud and the final bankruptcy of his company? Shortly after Parmalat's declaration of bankruptcy, PricewaterhouseCoopers $(\mathrm{PwC})$ audited the company's real accounts in an attempt to reconstruct how the $€ 14.2$ bn composing Parmalat's debt had actually been spent. Table 1 presents a summary of their findings.

\section{INSERT TABLE 1 HERE}

According to $\mathrm{PwC}, 38 \%$ of $€ 14.2 \mathrm{bn}$ was spent acquiring companies and other assets. The single biggest item (46\%) is the payment of the financial burden itself: payments toward bond holders, bank charges and fees (€2.8bn), and almost $€ 1 \mathrm{bn}$ of taxes (mostly undue since the profits on which taxes were paid were largely non-existent). ${ }^{8}$ The same report puts the amount of money “diverted" from Parmalat at $€ 2.3$ bn euro ( $16 \%$ of the debt). What these "diversions" include is a key point in the story.

The $€ 2.3$ bn estimate by $\mathrm{PwC}$ encompasses the money intentionally funnelled by Tanzi into companies owned by his family but not included in the consolidated balance sheet of Parmalat. These ventures were mostly loss-making machines unable to sustain themselves: for instance, $€ 500 \mathrm{~m}$ went to Parmatour and $€ 275$ to the Parma football club (see also Chiaruttini 2004a: 158). Unfortunately, PwC was not able to trace the final destination for roughly half of the $€ 2.3 \mathrm{bn}$ (the money went to a Uruguayan company and then moved to other accounts: Galloni and Reilly 2004). The report filed by Chiaruttini (2004a) puts the amount of diversions from Parmalat perpetrated by the Tanzi family at some $€ 930 \mathrm{~m}$ over 13 years. 
A second report prepared by PricewaterhouseCoopers in 2004 offers further evidence on the diversions. Capolino et al. (2004: 252-253) have made public parts of this report, including details about 60 transactions (“diversions") that occurred in $2000-2003$ and totalled $€ 438.16 \mathrm{~m}$. Calisto Tanzi was the recipient in five of them for a total of $€ 12.6 \mathrm{~m}(2.9 \%$ of overall amount; other recipients include two companies outside the consolidation perimeter and a law firm based in the US). An additional piece of this patchy mosaic comes from the Italian law enforcement agency that sifted out the Tanzis' bank accounts: their estimate for personal diversions is of $€ 21 \mathrm{~m}$ for the period $1993-2003$ and $€ 9 \mathrm{~m}$ for the years before. We have evidence that, also, part of this money was funnelled into loss-making businesses and the football club (Parma Court of the First Instance 2010: 490-492). In sum, all the companies owned by the Tanzi family were treated as if they were part of the same consolidated group while, in fact, they were not. This certainly constitutes a brazen violation of minority shareholders' rights and an illicit behaviour; yet it does not offer strong support for a purely wealth-maximization explanation.

Let us explore Tanzi's motivations further by relying on a counter-factual analysis of the alternative options he had and eventually decided to dismiss. An option is considered to be an alternative only if is possible to show that it was actually taken into consideration by the decision-maker at the time at which a given decision had to be made (a rather strict criterion). The two instances discussed below, i.e. the offer made by Kraft in 1988 and the four recapitalisations in the early 1990s, can also be interpreted as 'defining moments' of Tanzi's slippery slope to the fraud in the sense that they reveal "something important about a person's basic values and about his or her abiding commitments in life" (Badaracco 1997: 57). 
In 1988 the multinational giant Kraft made an offer to buy the whole Parmalat group, which was not listed at the time and entirely owned by the Tanzi family. This offer had actually been considered by Tanzi for a couple of months (Capolino et al. 2004: 54). Kraft was willing to pay Tanzi a considerable sum: some $€ 400 \mathrm{~m}$ at 1988 value, equivalent to $€ 852 \mathrm{~m}$ at 2015 value. ${ }^{9}$ Yet, the offer was eventually turned down. In this instance, Tanzi showed a preference for keeping the company's control over maximising his personal financial gains. The exact amount of money that was siphoned off the company for propping up the lifestyle of the Tanzis - and not for financing other loss-making ventures owned by the family - remains unknown, but it is unlikely that they would have had a lower standard of life had Tanzi accepted the Kraft offer. This is not to mention that in the end he lost the company he created together with his personal reputation, and was ultimately given a lengthy prison sentence.

Tanzi also showed a preference for keeping the company's control over acting in the best interest of the company itself. In the early 1990s, Parmalat had to be recapitalised four times (Chiaruttini 2004a: 67-72). Each recapitalisation fell short of solving the financial problems faced by the company. This was a direct consequence of Tanzi's desire to protect its majority stake. In his sworn testimony, the former CFO Tonna explicitly maintained that "the Tanzi family was unwilling to reduce their controlling interest in Parmalat below 51\% of the shares" (Parma Court of First Instance 2010: 140). According to the same CFO, Tanzi was further asked to inject fresh capital into the company three times in 1996, 2000 and 2002, but he always refused, fearing loss of control over the company (Parma Court of First Instance 2010: 1252). In 1996, given the lack of personal financial resources, Tanzi even chose to unlawfully finance his quota of capital increase through money indirectly borrowed from Parmalat itself (Parma Court of First Instance 2010: 1252). What would have happened if Tanzi had chosen the alternative path? 
A process of separation between management and ownership would have started: since Parmalat was indeed suffering from management problems, it is plausible that this would have turned out to be a healthy path for the company, and possibly financially beneficial to the Tanzi family as well. ${ }^{10}$ There is some reliable evidence about the market value of Parmalat's shares at the time of the 1996 unlawful capital increase. ${ }^{11}$ Based on the weighted average of the shares' prices during the first semester 1996, a single point in the quota of equity capital held by Tanzi was worth some $€ 32 \mathrm{~m}$ (at 2015 prices). ${ }^{12}$

Between 1988 and 1996 Tanzi's preferences do not seem to support a pure wealth-maximisation explanation. Quite paradoxically, had Tanzi been driven by a strong desire to maximise his economic wealth, he probably wouldn't have dismissed the alternative options he had over the years. As a result, we would not have witnessed one of the biggest bankruptcies and accounting frauds ever to have occurred in Europe.

\section{A behavioural approach to the Parmalat fraud}

Ruling out the wealth-maximisation explanation takes us only part of the way to a full understanding of the Parmalat case. It remains to explain why Tanzi failed to realise that his decisions were actually placing him on a very slippery slope. For instance, the amount of his personal financial resources made Tanzi's desire to retain full control over the company increasingly untenable as the latter grew into a truly multinational enterprise loaded with a relatively high level of debt.

A close read of the evidence reveals that some biases may have had a potentially decisive impact on the decision-making of Tanzi, thus offering some support for a behavioural explanation of the 
Parmalat bankruptcy. Four mechanisms deserve a closer scrutiny than they have yet received: managerial hubris, self-deception, emotions and the so-called 'endowment effect'.

\subsection{Managerial hubris and self-deception}

In the first stages of his career, Tanzi was a successful and innovative entrepreneur; however, he and the top executives he hand-picked from a close circle started to struggle when Parmalat gained a truly multinational reach. Signs of these emerging problems were already apparent in the late eighties; and they become ever more so in the following decade. ${ }^{13}$ Yet, Tanzi underestimated the gravity of these problems as well as their potential reach. In a statement he gave before the Milan court, he admitted the forgeries and added that he was always convinced that the business was still viable and the recovery feasible (Milan Court of Appeal 2010: 52). Indeed, in several instances during his pre-trial custody, Tanzi referred to the company he had created as "the little jewel" (il gioiellino) ${ }^{14}$ The CFO Tonna testified that the Cayman-based shell company Bonlat "was conceived by Tanzi as a temporary remedy that they could couple with a search for a more permanent solution to the financial problems of the Group" (Storelli 2005: 798-9, italics added).

A mechanism of self-deception is at work when a "person deliberately refuses to gather all available evidence because he strongly fears that it will tell against some of his cherished beliefs" (Elster 1979: 174). People involved in long-term fraud often "kid themselves" about their real situation. In his classical study on criminal violation of financial trust, Cressey (1953: 127) found that long-term violators (fraudsters) very often rationalise their behaviour as merely "borrowing" the money they take as opposed to "stealing": typically "the individual 'kids himself' or uses 'phony reasoning' that he is going to repay the amounts taken". 15 
In the case of Tanzi, self-deception appears to have been coupled with managerial hubris, or excessive self-confidence. ${ }^{16}$ While underestimating the problems, Tanzi also overestimated his ability to navigate the company away from troubles. The editor of a leading financial paper who had personally met with Tanzi before the discovery of the bankruptcy describes him as "a megalomaniac who always thinks positive" ${ }^{" 17}$. The state of overconfidence in which Tanzi and his entourage lived emerges neatly from a press statement that a senior executive and close aide to Tanzi repeated in several occasions in the early 1990s: "We aim to become the Coca-Cola of milk, and we are on the right track" (quoted in Capolino et al. 2004: 67). A number of factors contributed to pushing Tanzi's excessive self-confidence to a dangerous level. Firstly, the fact that he had been able to somehow navigate Parmalat away from all the troubles incurred in 33 years (as of 1994): this instilled in him a sense of boundless power and the belief that he was well equipped for solving all the problems the company had to face. At that time Parmalat was indeed regarded as a successful case and an example to follow (Caselli 1993), and Tanzi himself enjoyed rather good press coverage. ${ }^{18}$ In addition, he was awarded the knighthood by the Italian president of the Republic in 1984 and an honorary degree in economics from Parma University in 1992. Moreover, there was the unintended consequence of events such as the offer made to him by the multinational giant Kraft. It is easy to imagine that, when the company one has founded becomes appealing to a multinational giant, the next step could be to (erroneously) think that one can compete with the multinational giant on equal terms. ${ }^{19}$ 


\subsection{Emotions and the 'curse' of ownership}

Tanzi had the opportunity both to sell the whole company at a rather attractive price and to reduce his quota of shares, making considerable profit. However, selling the company one has created, or simply losing control over it, has some cost. We know from behavioural literature that owners, such as Tanzi, may display a tendency to resist selling possessions. This tendency, often called the 'endowment effect', appears to have been particularly acute in the case of Tanzi (see previous section). In this regard, emotions seem to have played a much bigger role than has yet been recognised. More specifically, a series of factors inherent to Tanzi's personal story may have had a critical impact. He was born in a small town of some 10,000 inhabitants, and yet he managed to turn the family business into a truly multinational company, acquiring prestige among his fellow citizens and beyond. He went from being the son of a local small entrepreneur to a successful businessman able to fly across the world in his private jet. In a sense, prestige and reputation had the unintended consequence of increasing the emotional cost and thus pushing him towards an unlawful path. In addition, selling the company would have meant losing his place among the few "captains of industry" that Italy had at the time, and becoming "just" a considerably wealthy person.

In a statement Tanzi gave of his own accord before the Bologna Court of Appeal in March 2012, he told the judges: "I regret the state of exaltation I was living in at that time [when the fraud was perpetrated] which concealed from myself the real state of the Group and didn't allow me to understand that I would have never got out of the tunnel of debts and the spiral of criminal offences I was making”, ${ }^{20}$ When Tanzi was summoned by the president of CONSOB, the Italian equivalent of SEC, in December 2003, he suddenly burst into tears while presenting the real situation of Parmalat. ${ }^{21}$ The dream of a lifetime was over. 


\section{How the Parmalat fraud escalated}

By definition, in "slippery-slope" fraud (Levi 2008: xvii-xix and 1-2) there is no single turning point that separates the inception stage from the escalation. However, as blurred as the transition may be, inception and escalation represent two analytically distinct phases. If we look back at Figure 1, it is plausible that the fraud entered a different phase around 1996 when it started to spiral out of control. Inception and escalation are different in nature, as their underlying mechanisms may differ greatly. While the failures of judgment discussed earlier mainly pertain to the first phase of the Parmalat fraud, other distinct mechanisms gained prominence during the escalation phase. For instance, after the initial decisions to unlawfully "fix up" the accounts, Tanzi became trapped in an escalation of commitment. ${ }^{22}$ As a consequence, he started to commit even greater resources to his unlawful and disastrous course of action: a type of behaviour often witnessed among so-called "rogue traders" when they try to recoup unlawfully generated losses (see, e.g., Gapper 2011, more generally Staw 1981). In 2003, the Parmalat's executives even placed some "bets" in the derivatives market for a nominal value of some $€ 1.5 \mathrm{bn}$ (Chiaruttini 2004a: 341-343). The longer the fraud went on undetected, the higher the incentives for keeping the hazardous conduct. During a business meeting held in late October/early November 2003, Tanzi, his son and another top executive explicitly told the newly appointed CFO that they were confident that the way they had "patched up" the balance sheet to cover the hidden debt would continue to work in the future since it had been working up to that point (Capolino et al. 2004: 189). After that meeting, the CFO resigned. ${ }^{23}$

The failures associated with Tanzi's decision-making process do not emerge as unique to his case, but rather the opposite (see, e.g., Salter 2008 on Enron). Why, then, do bankruptcies such as that of Parmalat not happen more often? As a single case study, it is well beyond the scope of 
this paper to offer a definitive answer. However, it is worth noting that the usual mechanisms to redress individual failures all failed in the case of Parmalat. These include the corporate governance structure, external auditors, rating agencies (if the company is rated), market analysts and regulatory bodies (for a more extensive discussion of these failures, see Campana 2013: 1113; also Chiaruttini 2004a, 2004b, and 2004c; Catino 2010). For instance, Parmalat's corporate governance was particularly inadequate and failed to redress Tanzi's failures. The Executive Board was widely dominated by the Tanzi family with little guarantee given to the minority shareholders. ${ }^{24}$ In addition, the Internal Auditing Office - a supervisory board elected by the shareholders - consisted of a single person reporting directly to the CFO and not to the board; and the Board of Statutory Auditors proved to be rather ineffective in raising any question as to the way the company was managed. ${ }^{25}$ Some of the external safeguards did not do a better job, either: the Italian Securities and Exchange Commission (CONSOB) first placed Parmalat under scrutiny only in March 2003, hence disregarding several warning signals flagged up in the years before (see Campana 2013: 11-13). The same holds true for the external auditors Grant Thornton (1990-1998) and Deloitte \& Touche (1999-2003) that also disregarded red flags and shortcomings. ${ }^{26}$ Safeguards can also be weakened by informal mechanisms. For instance, interpersonal trust may have the unintended consequence of preventing the detection of a fraud. Luciano Del Soldato, a Parmalat senior accountant who pleaded guilty, recalled a meeting with Calisto Tanzi in late 2003 when the financial situation was already fatally compromised. On that occasion, Tanzi sounded positive about the outcome of the crisis and outlined to Del Soldato his strategy to get the company out of trouble. Del Soldato testified that, after the meeting, "he decided to trust Tanzi as always [...], given the trust he had in Tanzi for what he had done until that moment" 
(Court of First Instance of Parma: 117, italics added). As a consequence, he didn't blow the whistle.

\section{Conclusions}

Management fraud constitutes a diverse set of phenomena underpinned by a variety of motivations (Levi 2008: xix; see also Schuchter and Levi 2013 and 2015 for additional first-hand evidence derived from interviews with 'elite' white-collar offenders). As Levi (2008) has compellingly shown, in some instances management fraud can be aptly explained by a costbenefit paradigm premised on the notion that individuals act by following purely economic motivations. This is the case, for instance, of the so-called 'phantom capitalists' involved in 'preplanned frauds' (Levi 2008). This paper has sought to expand on this work by looking at a different phenomenon, namely genuine Schumpeterian entrepreneurs who had strived to promote innovation and to generate wealth and who intentionally embarked on an unlawful path despite the (severe) expected consequences of their actions - including destroying everything they had managed to create. It is puzzling that economic actors with such a track record of success, thus arguably able of making rational calculations, may fail to adequately assess the (changing) circumstances in which they operate. According to a substantive theory of rationality, one should expect rational actors to possess an objective description of reality (Simon 1986: S209-S201). The story of Calisto Tanzi has shown that this is not always the case.

The main focus of the article has been on the inception stage of the Parmalat fraud (different sets of mechanisms may be at play at different stages). The paper has first qualified the often-cited greed explanation as a wealth-maximisation preference held by rational economic actors. 
Relying, also, on a counterfactual analysis of the 'defying moments' of Parmalat's slippery slope to the fraud and bankruptcy, it has shown that Tanzi's decision to falsify the company's financial statements had mostly to do with his desire to keep control over the company he had created. The evidence discussed shows little support for a pure wealth-maximising rational choice calculation. Contrary to a widespread narrative, greed does not appear to have played a crucial role in this instance.

This leads us to the second question addressed by the paper, namely why an innovative and rather successful entrepreneur failed to adequately assess the circumstances in which he was operating (i.e. acquiring an objective description of reality). The paper has argued that a behavioural approach, with its focus on biases and errors in judgment, is the best candidate to address this question, and to explain this specific type of fraud (this does not imply that a classic rational choice approach is not suitable to explain other types of fraud or that we should always reject such an approach). The case of Tanzi appears to be an instance of failure of rationality, which was induced by a number of behavioural mechanisms: self-deception, overconfidence, the endowment effect and emotions. A series of factors, resulting from Tanzi's personality as well as his entrepreneurial career and life story, may have reinforced these mechanisms. Although possibly not decisive, the evidence discussed offers some good support for a behavioural explanation of Tanzi's slippery slope. This is in line with the interpretation of Enron's bankruptcy given by Salter (2008). However, it does not lend support to the claim by Braithwaite and Geis (1982: 302) that corporate crimes are not crimes of passion or emotions, but are instead "calculated risks taken by rational actors". On the contrary, emotions and other biases appear to have played a much bigger role than has yet been recognised. 
More generally, the story of Calisto Tanzi is that of a genuine Schumpeterian entrepreneur driven by "the dream and the will to found a private kingdom usually $[\ldots]$ also a dynasty" and by "a joy to create" (Schumpeter 1934: 93). His story has shown that, while this mix of creative spirit and confidence is a driving force in fostering economic development, it also contains within itself the seeds of potential crises. Take, for example, confidence. It is a constituent element of entrepreneurship since an individual with a higher level of confidence than the average person is required to start a venture. A higher-than-average level of confidence has been shown to positively impact a CEO's investments and achievements in innovation as well as the level of patents (Hirshleifer et al. 2010; on the positive side of overconfidence see also Goel and Thakor 2008). However, there exists a dark side in all of this: an excessive dose of confidence hubris - exposes entrepreneurs to a considerable risk of failing to assess a situation, and can therefore lead them to the wrong decision. Such decisions are more difficult to redress when the positions of CEO and chairperson are held by the same individual, who is also the founder of the company.

The paper has also highlighted that the prospect of losing a good reputation and prestige acquired over the years may not necessarily prevent entrepreneurs and executives from taking unlawful courses of action. Not only that, but they may have the unintended consequence of nudging economic actors in the opposite direction, e.g. by raising the emotional costs of taking difficult decisions or by increasing the level of managerial hubris. Finally, as a single case study, this paper has not sought to shed light on the degree to which problematic activities are endemic within specific industries or the likelihood that the biases discussed above may lead to the actual collapse of a company. In the case of Parmalat they did, but more comparative research is certainly needed. 


\section{Interviews}

Stefania Chiaruttini, Independent accountant and expert advisor to the prosecutor's office, Milan, October 2011.

Gabriele Capolino, Business journalist, Milan, October 2011.

Vittorio Malagutti, Business journalist, Milan, October 2011.

Former Parmalat employee, Collecchio (Parma), February 2012.

Former Parmalat Group executive, Milan, September 2012.

\section{References}

Official documents and court files

Chiaruttini S. (2004a). Consulenza tecnica gruppo Parmalat. Profili di falsita' dei bilanci [Expert opinion for the Milan Prosecutor's Office].

Chiaruttini S. (2004b). Consulenza tecnica “Gruppo Parmalat”. Attivita' di revisione svolta da Deloitte \& Touche [Expert opinion for the Milan Prosecutor's Office].

Chiaruttini S. (2004c). Integrazione consulenza tecnica Parmalat [Expert opinion for the Milan Prosecutor's Office].

Milan Court of Appeal (2010). Case against Bonici Giovanni +7. Justification for the verdict.

Milan Court of First Instance (2008). Case against Barachini Enrico + 7. Justification for the verdict.

Parma Court of First Instance (2010). Case against Barachini Enrico + 16. Justification for the verdict.

Parmalat Finanziaria (2004). Extraordinary Commissioner's report on the reasons of the insolvency of Parmalat Finanziaria S.p.A. and those of its Subsidiaries.

$\underline{\text { Books and Articles }}$

Arjoon, S. (2008). "Slippery When Wet: The Real Risk in Business". In Journal of Markets \& Morality, 11:1, 77-91.

Badaracco, J. (1997). Defining moments: When managers must choose between right and right. Boston: Harvard Business Press.

Baron J. (2008). Thinking and deciding. New York: Cambridge University Press. 
Becker, G. S. (1974). “Crime and punishment: An economic approach”. In Becker G. S. and Landes W. M. (eds), Essays in the Economics of Crime and Punishment, National Bureau of Economic Research, 154.

Braithwaite J. (1992). Poverty, Power, and White-Collar Crime: Sutherland and the Paradoxes of Criminological Theory. In K. Schlegel and D. Weisbund (eds), White-collar crime reconsidered. Boston: Northeastern University Press.

Braithwaite J. and Geis G. (1982). "On Theory and Action for Corporate Crime Control. In Crime \& Delinquency, 28: 292-314.

Braithwaite J. and Makkai T. (1991). "Testing an Expected Utility Model of Corporate deterrence". Law and Society Review, 25:1, 7-40.

Bryce, R. (2004). Pipe dreams: Greed, ego, jealousy and the death of Enron. Cambridge MA: Public Affairs.

Buchanan B. and Yang T. (2005). "The benefits oand costs of controlling shareholders: the rise and fall of Parmalat". Research in International Business and Finance, 19: 27-52.

Capolino G., Massaro F. and Panerai P. (2004). Parmalat: La grande truffa. Milan: Milano Finanza.

Campana P. (2013). Parmalat. Case Study Series, Oxford University Centre for Corporate Reputation.

Caselli B. (1993). "Strategie di sviluppo di una azienda alimentare di successo: il caso Parmalat". Parma economica, June: 13-19.

Catino M. (2010). "Gatekeepers miopi? Aspetti organizzativi nel fallimento dei controlli", Stato $e$ Mercato, 89: 219-253.

Chambliss, W. J. (1967). "Types of deviance and the effectiveness of legal sanctions", Wisconsin Law Review, 703-719.

Cooper, A. C., Woo, C. Y., \& Dunkelberg, W. C. (1988). Entrepreneurs' perceived chances for success. Journal of business venturing, 3:2, 97-108.

COSO (1999). Fraudolent Financial Reporting 1987 - 1997: An analysis of US Public Companies. Committee of Sponsoring Organizations of the Treadway Commission.

COSO (2010). Fraudolent Financial Reporting 1998 - 2007: An analysis of US Public Companies. Committee of Sponsoring Organizations of the Treadway Commission.

Cressey D. R. (1953). Other people's money: a study in the social psychology of embezzlement. Glencoe: Free Press.

Cruver B. (2002). Anatomy of greed: The unshredded truth from an Enron insider. London: Arrow Books.

Elster J. (1979). Ulysses and the sirens. Cambridge and Paris: Cambridge University Press and Maison des Sciences de l'Homme.

Elster J. (1999). Alchemies of the mind. Cambridge: Cambridge University Press. 
Franzini G. (2004), Il crack Parmalat, Rome: Editori Riuniti

Galloni A. and Reilly D. (2004). "How Parmalat Spent and Spent”, Wall Street Journal, 23 July.

Gapper J. (2011). How To Be A Rogue Trader. London: Penguin.

Goel A.M. and Thakor A. V. (2008). "Overconfidence, CEO selection and corporate governance", Journal of Finance, 63(3): 2737-2784.

Hamilton S. and Micklethwait A. (2006). Greed and Corporate Failure. The Lessons from Recent Disasters. Basingstoke: Palgrave Macmillan.

Hayward M. L. A. and Hambrick D. C. (1997). "Explaining the Premiums Paid for Large Acquisitions: Evidence of CEO Hubris". Administrative Science Quarterly, 42(1): 103-127.

Hayward M. L. A., Shepherd D. A. and Griffin D. (2006). "A Hubris Theory of Entrepreneurship". Management Science, 52(2): 160-172.

Hirshleifer D, Low A. and S. H. Teoh (2012). "Are Overconfidence CEOs Better Innovators?", The Journal of Finance, 67(4): 1457-1498.

Kadish, S. H. (1977) "Some Observations on the Use of Criminal Sanc-tions in the Enforcement of Economic Regulations," in G. Geis and Meier RF (eds), White-Collar Crime Offenses in Business, Politics and the Professions. New York: Free Press.

Kagan, R. A., and Scholz, J. T. (1980). "The criminology of the corporation and regulatory enforcement strategies". Enforcing regulation, 67, 69-74.

Kahneman D. (2011). Thinking, Fast and Slow. London: Penguin.

Kahneman D, Knetsch J. L, and R. H. Thaler. (1991). 'The Endowment Effect, Loss Aversion, and Status Quo Bias'. The Journal of Economic Perspectives, 5:1, 193-206.

Kahneman D. and Tversky A. (1972). "Subjective Probability: A Judgment of Representativeness". Cognitive Psychology, 3, 430-454.

Kothari V. B. (2010). Executive Greed. New York: Palgrave MacMillan.

KPMG (2010). Fraud and Misconduct Survey. KPMG Forensic.

Langevoort D. C. (2000). Organised Illusions: A Bahavioral Theory of Why Corporations Mislead Stock Market Investors (and Cause Other Social Harms). In Sunstein C. R. (2000, eds). Behavioral Law \& Economics. Cambridge: Cambridge University Press.

Levi M. (2008). The Phantom Capitalists. Aldershot: Ashgate (first edition 1981).

Malagutti V. (2004). Buconero Spa. Dentro il crack Parmalat, Rome-Bari: Laterza

Malmendier, U., andTate, G. (2008). "Who makes acquisitions? CEO overconfidence and the market's reaction". Journal of financial Economics, $89: 1,20-43$ 
March J G and Simon H A (1958). Organizations. New York: Wiley.

Partnoy F. (2010). Infectious Greed. How Deceit and Risk Corrupted the Financial Markets. New York: Times Book.

Paternoster R. and Simpson S. (1993) A Rational Choice Theory of Corporate Crime. In R. Clarke and M. Felson (eds), Routine Activities and Rational Choice, New Brunswick (NJ): Transaction Publishers, 37-58.

Paternoster R. and S. Simpson (1996). "Sanction Threats and Appeals to Morality: Testing a Rational Choice Model of Corporate Crime". Law \& Society Review , 30: 3, 549-584

Rachlinski J. J. and Jourden F. (1998). 'Remedies and the Psychology and Ownership'. Vanderbilt Law Review, 51: 1541-1582.

Roll R. (1986). "The Hubris Hypothesis of Corporate Takeovers”. The Journal of Business, 59:2, 197-216.

Salter, M. S. (2008). Innovation corrupted: the origins and legacy of Enron's collapse. Cambridge (MA): Harvard University Press.

Schumpeter J. (1934). The theory of economic development. Cambrigde, MA: Harvard University Press.

Schuchter A. and Levi M. (2013). "The Fraud Triangle revisited”. In Security Journal, 1-15.

Schuchter A. and Levi M. (2015). "Beyond the fraud triangle: Swiss and Austrian elite fraudsters". In Accounting forum, 1-12.

Simon H. (1955). “A Behavioral Model of Rational Choice”, The Quarterly Journal of Economics, 69: 1, 99-118.

Simon H. (1986). "Rationality in psychology and economics”. Journal of Business, S209-S224.

Staw B. M. (1981). "The Escalation of Commitment to a Course of Action". The Academy of Management Review , 6: 4, 577-587.

Storelli C. (2005). “Corporate governance failures - Is Parmalat Europe's Enron?”. Columbia Business Law Review, 3: 765-826.

Sunstein C. R. (2000, eds). Behavioral Law \& Economics. Cambridge: Cambridge University Press.

Thaler R. H. and Sunstein C. R. (2009). Nudge. London: Penguin.

Tversky A. and Kahneman D. (1974). "Uncertainty: Heuristics and Biases”. Science, 185: 4157, 11241131.

Wheeler S. (1992). The Problem of White-Collar Crime Motivation. In K. Schlegel and D. Weisbund (eds), White-collar crime reconsidered. Boston: Northeastern University Press.

Zahra, S. A., Priem, R. L., \& Rasheed, A. A. (2005). The antecedents and consequences of top management fraud. Journal of Management, 31(6), 803-828. 
Table 1. Where the money went (1990-2003)

\begin{tabular}{|l|l|l|}
\hline Item & Euro/billion & $\%$ \\
\hline $\begin{array}{l}\text { Acquisition of companies and investments in permanent } \\
\text { assets }\end{array}$ & 5.4 & 38 \\
\hline $\begin{array}{l}\text { Payment of financial burdens and bank charges } \\
\text { (of which taxes }\end{array}$ & 6.5 & 45.8 \\
(of which towards the banking system & $0.9)$ & \\
(of which towards the bond holders & $2.8)$ & \\
\hline $\begin{array}{l}\text { Uses not comprised within the corporate purpose } \\
\text { (“diversions") }\end{array}$ & $2.5)$ & 16.2 \\
\hline Total & 2.3 & 100 \\
\hline
\end{tabular}

Source: Parmalat Finanziaria (2004: 4).

Figure 1. Net cash flow and professed liquidity per year, 1990-2002 (in €/mil)

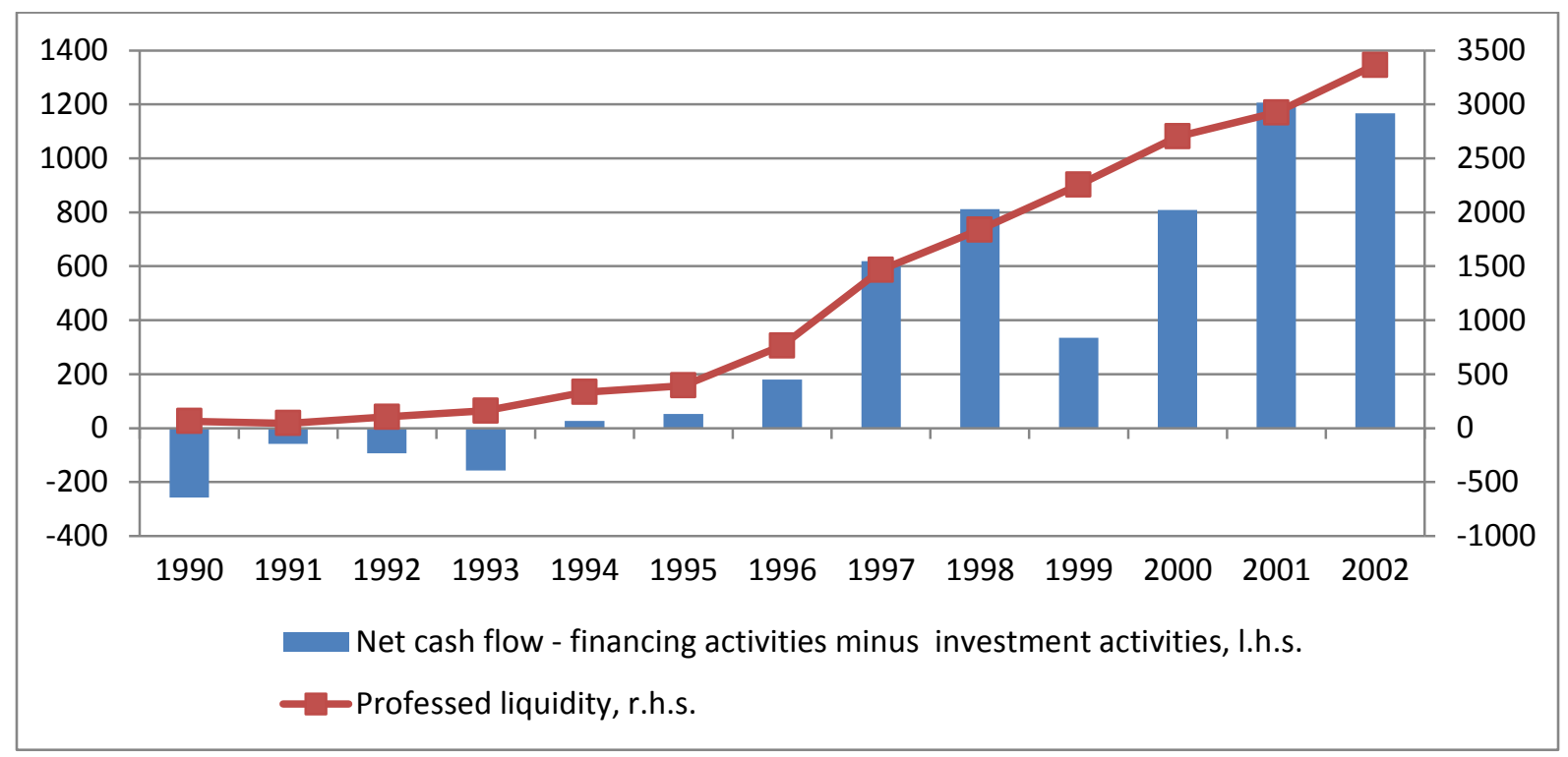

Source: Elaboration on Chiaruttini (2004a). 


\section{ENDNOTES}

${ }^{1}$ As epitomised by an interview he gave to a business magazine in 1987: "For a company, making profits is important, but only if they are then reinvested to the benefit of the community. I profoundly believe in this [...]. An entrepreneur should never act like Scrooge, who basks in the sea of coins" ("Altro che Danone", in Il Mondo, 16/11/1987, quoted in Capolino et al. 2004: 33).

${ }^{2}$ Gabriele Capolino, personal communication.

${ }^{3} \mathrm{http}: / /$ www.federalreserve.gov/boarddocs/hh/2002/july/testimony.htm

${ }^{4}$ Quoted in F. Federizzi and E. Livini, “Tanzi per anni a caccia di arricchimenti sfrenati”, in La Repubblica, 30/1/2004 and in 'Riesame Tanzi: avidita' alla radice del male”, in Vita.it, 29/1/2004.

${ }^{5}$ See Capolino et al. (2004: 27-28).

${ }^{6}$ More on the technicalities of the fraud is in Chiaruttini (2004a; 2004b and 2004c).

${ }^{7}$ These figures are based on the best reconstruction available of the real accounts, i.e. the one carried out by the independent accountant and expert advisor to the prosecutor's office Stefania Chiaruttini (2004a; see also 2004b and 2004c).

${ }^{8}$ See Chiaruttini (2004a: 378, Table 55).

${ }^{9}$ As reported by several newspapers at that time (Malagutti 2004: 91).

${ }^{10}$ In Italy this strategy was followed, for instance, by the owners of the FIAT group, the Agnelli family.

${ }^{11}$ Parma Court of First Instance (2010: 135).

${ }^{12}$ Parmalat was indeed seen as appealing by investors: a $20 \%$ increase in the company’s equity was successfully completed in 1996.

${ }^{13}$ As it emerges, for instance, from an article that appeared in the business daily Il Sole 24 Ore on 28/6/1988 ("La Kraft chiude per Parmalat").

${ }^{14}$ Stefania Chiaruttini, personal communication.

${ }^{15}$ For a discussion on ex-post rationalisation among fraudsters, see Levi (2008: Appendix A).

${ }^{16}$ Overconfidence and self-deception may act together and reinforce each other.

${ }^{17}$ Gabriele Capolino, personal communication.

${ }^{18}$ For instance, in an op-ed written for Corriere della Sera, the Italian leading daily, a well-respected economist praised Tanzi for being “a brave entrepreneur” and an example to follow: Giavazzi F., "Chi e' globale e chi no”, in Corriere della Sera, 5/9/1998.

${ }^{19}$ I am grateful to Federico Varese for bringing this point to my attention. An additional factor may have been the political connections he was able to establish over the years

${ }^{20}$ Italics added. Quoted in W. Galbiati "Tanzi: Mi pento per l' esaltazione di allora solo adesso mi rendo conto dei miei reati”, in La Repubblica, 23/3/2012.

${ }^{21}$ Gabriele Capolino, personal communication.

${ }^{22}$ On the concept of escalation of commitment, see Staw (1981). 
${ }^{23}$ In a country with very few multinational groups, the size of Parmalat could also have played a role in shaping Tanzi's incentives ("too big to fail").

${ }^{24}$ Four family members sat on the board, together with two of Tanzi's school friends, one long-term associate, four company executives, a lawyer and one accountant; the ratio of independent members to total board members was 15\% (Buchanan and Yang 2005: 42).

${ }^{25}$ See Parma Court of First Instance 2010: 1006-1007 and 1055. In July 2003, GovernanceMetrics International (GMI) gave Parmalat an overall rating of 4 (out of 10), and only 2.5 for board accountability (Buchanan and Yang 2005: 38).

${ }^{26}$ Parmalat fully complied with the provision of the law stating that the same company could serve as main auditor for a maximum of nine years. 